\author{
MaŁgorZata Kabat \\ Uniwersytet im. Adama Mickiewicza \\ $w$ Poznaniu
}

\title{
BUDOWANIE TOŻSAMOŚCI PRZEZ NAUCZYCIELA
}

\begin{abstract}
Aвstract. Kabat Małgorzata, Budowanie tożsamości przez nauczyciela [The Teacher's Construction of Identity]. Studia Edukacyjne nr 50, 2018, Poznań 2018, pp. 275-287. Adam Mickiewicz University Press. ISSN 1233-6688. DOI: 10.14746/se.2018.50.18

The article attempts to capture the complexity of explanations concerning the teacher's identity. Attention is paid to various dimensions and learning to build this identity in various spaces of the contemporary teacher's life and work. It considers these spaces from the position of I. Menter's concept that includes two sustainable areas: individual and institutional. In each of them there are metacognitive processes and meta-insights, necessary to construct a mature teacher's identity. The teacher's acquired knowledge and experience enriches the ability of individual learning as well as learning in the workplace, while serving the effective functioning and education of others in dynamically changing educational conditions.
\end{abstract}

Key words: teacher, identity, learning to build identity, school

Panować nad sobą, to najwyższa władza

Seneka

\section{Wprowadzenie}

Druga dekada XXI wieku jest postrzegana jako stan ciągłej i permanentnej zmiany. Pojawiające się w niej przekształcenia determinują sposób oswajania się z jej nieprzewidywalnością, odciskając piętno na systemie edukacji. Skutkuje to określoną aktywnością nauczającego, wynikającą nie tylko z jego akademickiego przygotowania oraz indywidualnych możliwości, ale też z przestrzennej struktury organizacyjnej i społecznej placówki oświatowej. Uwidacznia się tam złożoność funkcjonowania nauczyciela wraz z uformowaną tożsamością, dostrzeganą w szkolnej społeczności. Budowane przez lata personalne oblicze nauczającego oddziałuje na „kreowanie przyszłości, 
które zachodzi tylko wtedy, gdy się rozwijamy, rozumiemy zasady rządzące zmianami i umiemy wpływać na ludzi bez narzucania władzy"1.

Zacytowane słowa R.K. Coopera i A. Sawala wyraźnie podkreślają znaczenie procesu konstruowania przyszłości, w której podstawą są obecne warunki procesu edukacji, praca nauczyciela i ich wzajemne relacje. Zarysowana skomplikowana oświatowa sytuacja stwarza możliwość doświadczania jej bezpośredniości, drobiazgowości i powtarzalności. W niej nauczyciel manifestuje swoją tożsamość, próbując zaistnieć w konkretnym miejscu i czasie. Wymaga to od niego ukształtowania się wielu umiejętności i nowatorskiego postępowania, wiążącego się z przygotowaniem siebie i innych do radzenia sobie w płynnych realiach współczesności. Pomaga tej postawie nauczyciela krytyczne i refleksyjne myślenie, które z jednej strony utrwala indywidualne zręby oraz zachowanie określonych społecznych wzorów, a z drugiej następuje w większym lub mniejszym stopniu ich dezaktualizacja. Dlatego celem rozważań uczyniono poznanie procesu uczenia budowania się tożsamości przez nauczyciela $\mathrm{w}$ indywidualnej i instytucjonalnej przestrzeni oświatowego środowiska. Każda przestrzeń emanuje oczywistością, stałością, tymczasowością, rutyną i pewną dramaturgią zawieszoną na osi czasu, w której krystalizuje się nauczycielska tożsamość odmiennie rozpatrywana przez badaczy. Pojawiające się u nich argumenty stwierdzają, że wpływa na kształt edukacji, jak i charakter oraz współzależność przekształceń zachodzących między zewnętrzną rzeczywistością a zinstytucjonalizowaną przestrzenią szkolnego systemu. Uwidacznia się więc obszar wart eksploracji, obejmując przeanalizowanie uwarunkowań wskazujących na formowanie tożsamości nauczyciela nie tylko jako indywidualnego tworu, ale i zaznaczającego się społecznego procesu budowania oraz uczenia się jej w zmiennych przestrzeniach edukacyjnej teraźniejszości.

\section{Wieloznaczne ujęcia tożsamości}

Zaprezentowany wyżej trop dociekań stanowi przedmiot zainteresowań współczesnej pedeutologii, obejmujący szeroko rozumianą tożsamość nauczyciela ${ }^{2}$. Samym terminem tożsamości nie zajmowano się w okresie przednowożytnym, gdyż człowiek otrzymywał ją dzięki tradycji, jak i poprzez przynależność do klasy społecznej ${ }^{3}$. Nowożytne zmiany warunków przyczyniły się do zajęcia się tym ciekawym zagadnieniem. Upływający czas wraz s. 270 .

${ }^{1}$ R.K. Cooper, A. Sawal, Inteligencja emocjonalna w organizacji i zarzadzaniu, Warszawa 2000,

${ }^{2}$ H. Kwiatkowska, Tożsamość nauczycieli. Między anomia a autonomia, Gdańsk 2005.

${ }^{3}$ M. Środa, Indywidualizm i jego krytycy, Warszawa 2003, s. 181. 
z rozwojem nauki i techniki przekształcał egzystencję człowieka i jego aktywność. Mimo syndromu cywilizacyjnego przyspieszenia zauważono, że każda ludzka istota posiada swoją tożsamość i niepowtarzalną strukturę siebie. Wywołało to dążenie do poznania tego niezwykłego fenomenu. Zaczęto go analizować nie tylko w kategoriach indywidualnych, ale i społecznych. Zarysowały się więc dwa różne wymiary wzajemnie dopełniające się i kształtujące określoną jednostkową tożsamość, jak podaje E. Wenger ${ }^{4}$. Badania autora potwierdziły, że pojęcie tożsamości historycznie ewaluowało, by w swej etymologii uwzględnić dychotomiczne ujęcie. Podobne biegunowe rozwiązanie pojawiło się w definicji A. Cooleya, sformułowanej w 1902 roku $^{5}$. Naukowiec wprowadził do niej pojęcie "lustra”, pisząc, że poznanie siebie jest częścią refleksyjnego procesu uczenia się postaw, zachowań, ról, jakie kumulują się w konkretną tożsamość. Zaprezentowane wyjaśnienie kontrastowało z określeniem M. Mead ${ }^{6}$. Badaczka sądziła, że tożsamość jest procesem związanym z interakcjami społecznymi, jakich doświadcza jednostka odgrywając swoją rolę w społeczeństwie. Na poparcie swojej tezy wyodrębniła trzy czynniki, to jest: osobowość, interakcje i strukturę społeczną, które wywierają wpływ na osobę. Większe zamieszanie w naukowych kręgach wywarła definicja zaproponowana przez E. Goffmana ${ }^{7}$. Stwierdził on, że istotne są dyskusje odnoszące się do tego, iż każdy posiada wewnątrz siebie „kilka” innych osób, które ujawniają się w zależności od odbieranej sytuacji. Autor oparł swój wywód na założeniach M. Mead. Wyróżnione przez nią czynniki znalazły się również w koncepcji E. Ericksona ${ }^{8}$. Naukowiec stwierdził, że u człowieka formuje się tożsamość ego mająca swoją ciągłość czasoprzestrzenną. Oddziałuje na wymiar osobisty i społeczny, zapewniając stabilny charakter zachowania. Z kolei zróżnicowana tożsamość ujawnia się w zależności od doświadczanej sytuacji, jak pisze J.S. Ball ${ }^{9}$, co ma miejsce na przykład w środowisku szkolnym.

Budowanie tożsamości może następować poprzez istnienie świadomości przemijania. Zwrócił na to uwagę E. Husserl ${ }^{10}$. Odwołał się on do przeszłości umożliwiającej gromadzenie doświadczeń pomagających kształtować konkretną indywidualność. Nazwał to retencją. Dzięki niej człowiek, a także

4 E. Wenger, Communities of practice: learning, meaning and identity, Cambridge 1999, s. $146-149$.

${ }^{5}$ Definicja w pracy: J.A.F. Castañeda, Teacher identity construction: exploring the nature of becoming a primary school language teacher, November 2011, s. 20.

${ }^{6}$ M. Mead, Mind, Self, and Society, Chicago 1934, s. 62.

7 E. Goffman, Stigma: Notes on the management of spoiled identity, London - New Jersey 1963, s. 22.

8 British Educational Research Journal, 2003, 29(2), s. 227-242.

9 S.J. Ball, Self and identity in the context of deviance: the case of criminal abortion. Theoretical perspectives of deviance, New York 1972, s. 146.

10 K. Michalski, Logika i czas, Warszawa 1988, s. 146. 
nauczyciel uświadamia sobie, że przechowuje poznawane wcześniej rzeczy, zjawiska, fakty, którym później nadaje nowy sens.

Dychotomiczną jedność tożsamości widać w określeniach M. Jarynowicz. Sądzi ona, że „własna tożsamość to posiadane przez podmiot wizje własnej osoby, a dokładniej wizje tego, co dla autocharakterystyki jest najważniejsze, najbardziej wartościowe i specyficzne"11. Tę jedność różnorodności spotykamy także u M. Melchior. Uważa, że „jednostka identyfikuje siebie samą przez innych oraz poprzez usytuowanie jej we współczesnym świecie"12. Współczesny świat oraz środowisko szkolne nauczyciela dostarcza w tym zakresie wielu informacji. Dowiadujemy się, kim jesteśmy, jak mówimy, co mówimy i co mamy na myśli. Wobec tego, rozpiętość myślenia nauczyciela w czasie i przestrzeni wynika z warunków otoczenia, zachęcających lub zniechęcających do budowania swego oblicza oraz podejmowania się lub nie różnorodnych działań, w których zaznacza się jego tożsamość umożliwiająca realizację wspólnotowej aktywności, o czym pisze J. Dyer ${ }^{13}$. W niej każdy pedagog buduje i umacnia swoją indywidualną oraz zawodową tożsamość, która łączy się z poczuciem istnienia ,ja we mnie", jako specyficznego oraz odrębnego stanu psychicznego i duchowego ${ }^{14}$. Podobne objaśnienie znajdziemy w pracach L. Witkowskiego, który widzi ją jako

spójność powiązania elementów składowych własnego istnienia, bytu w danym momencie życia, poczucia trwania i ciągłości biograficznej. Poczucie odrębności wynika z faktu przynależności do pewnej zbiorowości społecznej $(\ldots)^{15}$.

Czasami to poczucie nauczycielskiego ,ja" uwidacznia się w wielorakich szkolnych zdarzeniach, a czasami ginie $\mathrm{w}$ wielości spraw do zgłębienia i załatwienia. Jednocześnie $\mathrm{w}$ tych momentach manifestują się zdobyte kwalifikacje oraz kondycja siebie jako człowieka i profesjonalisty. Zgłębił te kwestie K.E. Johnson ${ }^{16}$, zauważając, że znaczenie ma nie tylko znajomość siebie uwidaczniająca się podczas studiów, w czasie których zdobywa się wiedzę o sobie pochodzącą od innych, jak „być nauczycielem”. Umożliwia to rozróżnienie tworzenia osobistego i zawodowego wymiaru tożsamości.

Tożsamość zawodowa nauczyciela odnosi się na ogół do tego, jak sam nauczyciel postrzega siebie, swoją interakcję ze środowiskiem oświatowym.

${ }^{11}$ M. Jarynowicz, Spostrzegać samego siebie, Studia Psychologiczne, 1989, 27, 2, s. 93.

${ }_{12}$ M. Melchior, Spoteczna tożsamość jednostki, Warszawa 1990, s. 233.

${ }^{13}$ J. Dyer, Language and identity, London 2007.

14 Tamże, s. 101.

${ }^{15}$ L. Witkowski, Tożsamość i zmiana. Wstęp do epistemologicznej analizy kontekstów edukacyjnych, Torun 1988, s. 111-120.

${ }^{16}$ K.E. Johnson, Every experience is moving force": identity and growth through mentoring, Teaching and Teacher Education, 2003, 19, s. 787-800. 
Zwrócił na to zagadnienie uwagę R. Groningen ${ }^{17}$. Stwierdził, że efekt doznawanej satysfakcji z wykonywanej pracy zawodowej, zaangażowania się w nią, posiadanie samooceny siebie, zmiana motywacji prowadzi do osiągania jak najlepszej skuteczności w procesie dydaktyczno-wychowawczym. Do tych wyróżnionych właściwości D. Beijaard, P.C. Meijer i N. Verloop ${ }^{18}$ dodali ciągłą reinterpretację zdobywanego doświadczenia osobistego, społecznego i zawodowego, jakie powinny być w równowadze.

Profesjonalna nauczycielska praktyka pokazuje jednak, że pracownicy oświaty odznaczają się zróżnicowanym doświadczeniem i tożsamością. Spowodowane jest to, zdaniem D. Beijaard, liczbą lat pracy nauczającego, powiększając doświadczenie i profil zawodowy. Istotną rolę odrywa tu obszar fachowej i osobistej wiedzy, które wyznaczają możliwości indywidualnego oraz instytucjonalnego funkcjonowania i rozwoju nauczającego, co podnosi K. Van Veen $^{19}$. Dla tego autora określona działalność łączy się z jakością gromadzonej wiedzy, stabilizującej obraz ,ja” nauczyciela z przekonaniami, które w zasadniczy sposób oddziałują na jego nauczycielskie dyspozycje. Szczegółowo opisał je J.N. Cohen ${ }^{20}$, który na podstawie przeprowadzonych analiz stwierdził, że indywidualne i grupowe przekonania w większym lub w mniejszym stopniu decydują o jakości wywiązywania się pedagoga z jego zawodowych obowiązków, różnicując tym samym indywidualną oraz instytucjonalną przestrzeń funkcjonowania. Zaznacza się w tych przestrzeniach albo wyrazistość sylwetki nauczyciela, albo jego szarość i znikanie wynikające z przyjętych zasad regulujących wykonywanie oświatowych czynności. Odciskają one ślad na dynamicznych społecznych układach w przestrzennej strukturze organizacyjnej instytucji, w których pojawiają się ewentualne dyferencjacje między osobistymi a wspólnotowymi przekonaniami nauczycielskiej grupy. Te rozbieżności dokładają cegiełkę do zawodowego sukcesu lub porażki nauczyciela, stanowiąc zarazem element budowy danego wymiaru tożsamości.

Ponadto, informacje pochodzące z przekonań mogą posłużyć do formowania lustrzanej, dyfuzyjnej bądź dojrzałej tożsamości, które opisała M. Cupryjak $^{21}$. Tworzą się one w warunkach edukacyjnego otoczenia, w jakich każdy nauczyciel pragnie wywiązać się ze swoich zadań, ale i koncentruje się na

17 R. Groningen, Teacher`s sense of their professional identity, Esther T. Canrinus, 2011, s. 53-54.

18 D. Beijaard, P.C. Meijer, N. Verloop, Reconsidering research on teachers' professional identity, Teaching and Teacher Education, 2004, 20, s. 107-128.

19 K. Van Veen, 'Analysing teachers' working conditions from the perspective of teachers as professionals: The case of Dutch high school teachers, [w:] Critiquing praxis: Conceptual and empirical trends in the teaching profession, red. J. Ax, P. Ponte, Rotterdam 2008, s. 91-112.

20 J.N. Cohen, Getting recognized: Teachers negotiating professional identities as learners through talk, Teaching and Teacher Education, 2010, 26, s. 473-481.

21 M. Cupryjak, Tożsamość w kontekście transformacji. Raport z badań, http://dx.doi.org/ 10.12775/PBEE.2013. 
tym, co dzieje się w jego otoczeniu. Doświadczany przez nauczyciela dualizm i pogranicze przestrzeni wyznacza odnalezienie własnego miejsca i okoliczności sprzyjających realizacji oraz wyzwań swojej profesji. Tymczasem, jak sądzi B. Zamorska,

w szkole wszystko musi być po coś wpisane w plany i celowe działania opracowane przez zespoły nauczycieli $(\ldots)^{22}$. Pojawia się $\mathrm{w}$ tym napięcie wskazujące na realizację zamierzeń instytucji, które konfrontowane jest $\mathrm{z}$ indywidualnymi planami nauczającego. Powoduje to u nauczyciela miotanie się wśród zmiennych poglądów, zaleceń władz, „niusów” z ministerstwa i personalnym zasymilowaniem „oczywistości” swojego środowiska. W tej zagmatwanej sytuacji najczęściej obserwujemy rozwój i doskonalenie się nauczyciela jako fachowca, który został przygotowany do pełnienia swoich zawodowych obowiązków zgodnie z technologiczną orientacją kształcenia ${ }^{23}$.

Technologiczna organizacja kształcenia pomaga osiągnąć kolejne stopnie w zawodowej karierze nauczyciela. Często jednak dzieje się to kosztem wykorzystywania gotowych konspektów zajęć metodycznych zawierających różnorodne materiały. Ich sile trudno się oprzeć ze względu na bardzo atrakcyjne rozwiązania tematów z danego przedmiotu nauczania. Ekspansywność tych materiałów jest tak duża, że próba wyrwania się nauczyciela z mentalnego zniewolenia i ich powielania jest skazana na porażkę, jak uważa D. Klus-Stańska ${ }^{24}$. Powód, jaki podaje autorka, to brak krytycznej refleksji nauczyciela wobec własnych pedagogicznych działań oraz niezdolność do zmiany utrwalanych nawyków ${ }^{25}$.

Pośród innych niekorzystnych czynników wymienia się brak wzmacniania indywidualnej i zawodowej tożsamości oraz wiedzy nauczyciela, która połączona jest z brakiem uświadomienia rutyny codziennych czynności. Staje się źródłem popadania w schemat i budowanie niekorzystnej tożsamości. Już J. Dewey ${ }^{26}$ podkreślił, że w życiu człowieka, a tym bardziej nauczyciela, istotne stają się refleksyjne działania wobec własnej osoby i wykonywanego zawodu. Szczególnie jest to ważne dla uczenia się budowania tożsamości nauczyciela, gdyż

strumień naszych przeżyć przepływa przez każdego nieustannie i każde z nich jest ciągiem innego, a każde posuwanie się naprzód z biegiem czasu nabierze dalszego trwania, które zbiera się po drodze $\mathrm{e}^{27}$.

${ }^{22}$ B. Zamorska, Codzienność granic jako miejsce ksztattowania się tożsamości nauczycieli, Forum Oświatowe, 2012, 1(46), s. 111.

${ }^{23}$ H. Kwiatkowska, Edukacja nauczycieli. Konteksty. Kategorie. Praktyki, Warszawa 1997, s. 66-73.

${ }^{24}$ D. Klus-Stańska, Mentalne zniewolenie nauczycieli wczesnej edukacji - epizod czy prawidtowość, Problemy Wczesnej Edukacji, 2005, 1, s. 58.

${ }_{25}$ Tamże, s. 59-60.

${ }^{26}$ J. Dewy, Jak myślimy, przekł. J. Mysłakowski, Lwów - Warszawa 1934.

${ }^{27}$ I. Wojnar, Bergson, Warszawa1985, s. 485. 
Przytoczone słowa I. Wojnar ilustrują etapy uczenia się nauczycielskiej tożsamości między innymi poprzez interakcje zachodzące między jednostką i społeczną wspólnotą.

Zatem, indywidualna oraz instytucjonalna przestrzeń funkcjonowania nauczyciela scala się $\mathrm{z}$ tworzeniem jego tożsamości $\mathrm{w}$ wymiarze osobistym, społecznym i zawodowym ${ }^{28}$. Jest uwarunkowana wieloma czynnikami o zmiennym i dynamicznym charakterze. Jednakże, jej trwałość zależy od konstytucji nauczyciela oraz jakości interakcji zachodzących między osobą nauczyciela a jego edukacyjną aktywnością, przyczyniającą się do zbierania doświadczenia i wiedzy w szkolnej przestrzeni.

\section{Uczenie budowania się tożsamości przez nauczyciela}

Obszerne definicyjne wyjaśnienia analizujące tożsamość nauczającego zaprezentowano w różnych wymiarach, kontekstach bliższego i dalszego otoczenia, uwzględniając zarazem fakty obiektywne i subiektywne. Jednak rzadko podejmowane są rozważania dotyczące uczenia się konstruowania własnej tożsamości przez nauczającego. Jest to dziś niebagatelna sprawa. Zwykle uczenie kojarzy się ze „zdobywaniem i przyswajaniem wiadomości lub umiejętności, jakie ma miejsce podczas nauki własnej lub jest instytucjonalnie zorganizowana" 29 .

W naszym współczesnym świecie funkcjonowanie nauczyciela i jego działalność stwarza możliwość zakorzenienia się w „płynnych" ${ }^{30}$ przestrzeniach obecnej rzeczywistości. Modyfikacje w takim otoczeniu wymagają od nauczyciela potrzeby uczenia się i radzenia sobie z przewidywanymi i nieprzewidywanymi edukacyjnymi sytuacjami i zadaniami. W tym celu niezbędne są zdobyte ogólne i specjalistyczne kwalifikacje, które ukierunkowują nauczyciela na formowanie się umiejętności uczenia się także w swoim miejscu pracy. Obowiązujący system edukacji raczej pokazuje strategie wiążące się z przygotowaniem do osiągania standardów zawodowych i stopni nauczycielskiego wtajemniczenia, niż poznawaniem uczenia się „bycia nauczycielem”.

Pojęcie „być nauczycielem”, jak wykazał Raport Ramseya z $2000^{31}$ roku przedstawia kandydata na nauczyciela, który w minimalnym stopniu gro-

${ }_{28}$ B. Karolczak-Biernacka, Poczucie tożsamości i czynniki ją zakłócające, Zdrowie Psychiczne, 1992, 1-2, s. 107.

29 Stownik współczesnego języka polskiego, red. A. Sikorska-Michalak, O. Wojniłko, Warszawa 1998 , s. 461.

30 Z. Bauman, Niecodzienność nasza codzienność, [w:] Barwy codzienności. Analiza socjologiczna, red. M. Bogunia-Borowska, Warszawa 2009, s. 78.

31 Raport Ramseya 2000 znajduje się w pracy: A. Graham, R. Phelps, Bening a teacher: developing teacher identity and enhancing practice through metacognitive and reflective learning processes, Australian Journal of Teacher Education, 2003, 27, 2, s. 10. 
madzi doświadczenie i wiedzę na temat wybranego zawodu. Uczy się raczej technicznego funkcjonowania, co zawęża naturalne zdolności intelektualne i posiadane zasoby. Pojawiające się niekorzystne procesy pogłębia fakt dostrzegania braku zaangażowania się starszych kolegów w proces uczenia się i doskonalenia prowadzący do planowania w ciekawy sposób powtarzalnych zawodowych czynności. Zniechęca do tego mentalność nauczycielskiej społeczności, panujący w niej klimat ograniczający reagowanie na pojawiające się środowiskowe problemy. Te i wiele jeszcze innych czynników oddziałują na nauczycielską tożsamość, w której z mniejszą lub większą częstością urzeczywistniają się procesy metapoznawcze i metanauczanie.

Po raz pierwszy pojęcie metanauczanie pojawiło się w pracach J. Biggsa ${ }^{32}$. Objaśnił je autor na poziomie interdyscyplinarnym i odniósł do świadomości człowieka mającego nadzór nad kontrolą nauki własnej. Łączy się ona z organizacją własnych procesów nauczania i uczenia się, w których istotną rolę odgrywa metapoznannie, samorealizacja i doświadczenie. Do tych wyróżnionych elementów przez N. Jacksona, I. Menter 33 dołączył wyobraźnię. Pomaga nauczycielowi uświadomić naturę metapoznania w trakcie nauki własnej. Angażuje widzenie indywidualnych i instytucjonalnych spraw w określonej przestrzeni, umożliwiając dążenie do zrównoważenia funkcjonowania w dynamicznym szkolnym środowisku. Zrównoważone widzenie siebie i zewnętrznego horyzontu swej zawodowej działalności jako całości bycia w nauczycielskiej wspólnocie wynika z systemu wiedzy, doświadczenia i wywiązywania się z zawodowych celów. Nie chodzi tu o indywidualne przeżywanie edukacyjnych problemów, ale o takie rozpoznawanie pedagogicznych możliwości, by móc „planować działalność dydaktyczno-wychowawczą, zarządzać i kierować uwagą, decydować o postępie nauki, samokontroli siebie sprowadzającej się do realizacji zadań, sytuacji, samooceny oszacowującej własne postępy w stosunku do zewnętrznych kryteriów, samowzmocnienia, odpowiadając za osiąganie sukcesu" ${ }^{34}$.

W tym opisie koncepcji I. Mentera bierze się pod uwagę rozmaite czynniki nawzajem na siebie oddziałujące i warunkujące metapoznanie oraz uczenie się budowania nauczycielskiej tożsamości, co pokazano na poniższej grafice.

32 J. Biggs, The role of metalearning in study processes, British Journal of Educational Psychology, 1985, 55 .

${ }_{33}$ I. Menter, Teacher - formation, freaing and identity. A literature review, December 2010, s. $19-21$.

34 N. Jackson, Developing the concept on metalearning, Innovations in Education and Teaching International, 2004, 41, 4, s. 394-395. 


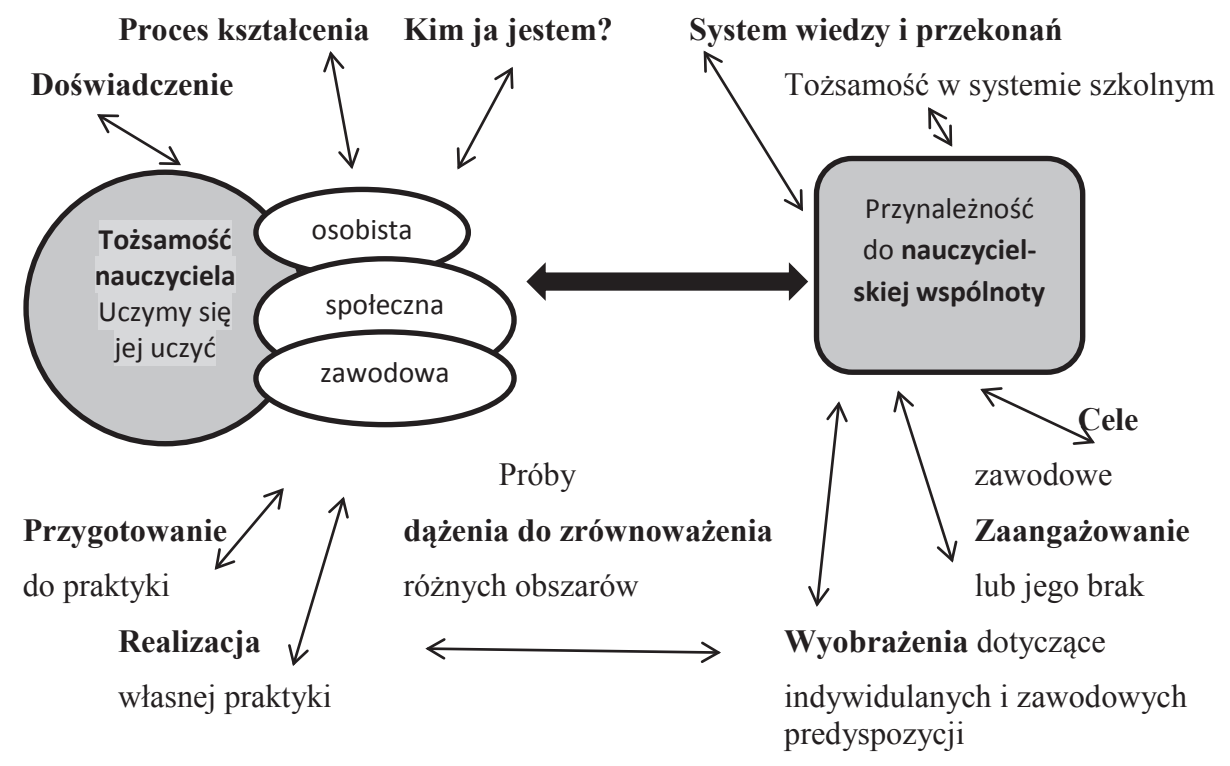

Ryc. 1. Opracowanie własne tworzenia tożsamości nauczyciela na podstawie książki: I. Menter, Teacher - formation, freaing and identity. A literature review, December 2010, s. $19-47$

Punktem wyjścia interpretującym ten złożony schemat są podejmowane próby przez nauczyciela dążące do zharmonizowania różnych elementów występujących w indywidualnych i instytucjonalnych przestrzeniach placówki oświatowej. Ważnym składnikiem zaprezentowanego układu elementów jest budowanie tożsamości, w której znamienną rolę odgrywają metaprocesy poznawania i uczenia się indywidualnego, i w miejscu pracy nauczyciela. Dzięki nim dowiaduje się, kim jest jako nauczyciel i jako człowiek, jaka jest granica „ja” i „nie - ja”, jaka jest odrębność „ja” od otoczenia, jakie zyskuje poczucie tożsamości ze względu na upływający czas, jaką buduje strukturę osobowości wskazującą na konkretny „rys” charakteru, co również podkreśla B. Olczak-Krzyżanowska, B. Gołębniak czy W. Dróżka ${ }^{35}$. Teoretyczno-badawcze rozwiązania wymienionych autorów sytuują rozważane składniki ,ja” nauczyciela nie w izolacji z innymi elementami, ale jako integralną cząstkę własnej i grupowej tożsamości. Spoiwem, jak zaznacza I. Menter, jest doświadczenie nauczającego, wzbogacane nie tylko w procesie profesjonalnego kształcenia,

35 B. Olczak-Krzyżanowska, Poczucie tożsamości zawodu nauczyciela, Nauczyciel i Szkoła, 1999, 1(6), s. 19-20; B. Gołębniak, Ku pedeutologii refleksyjnej - od agresywnej pewności do łagodnej perswazji, Teraźniejszość - Człowiek - Edukacja, numer specjalny, Wrocław 2001; W. Dróżka, Generacja wielkiej zmiany. Studium autobiografii średniego pokolenia nauczycieli polskich, Kielce 2008 $i$ inne. 
ale i w procesie przygotowania do realizacji swojej nauki i praktyki. Pomocą $\mathrm{w}$ przygotowaniu do praktyki i zdobywaniu doświadczenia jest utrzymanie $\mathrm{w}$ równowadze związku między różnymi wymiarami tożsamości, co uwypuklił I. Menter i P. Kleiman ${ }^{36}$. Badacze stwierdzili, że bogactwo i intensywność doświadczeń sprzyjających budowaniu tożsamości pochodzi z indywidualnego procesu nauczania i uczenia się ${ }^{37}$. Umożliwia ono manifestowanie działań nauczyciela, zdobywanie wiedzy zawodowej i wiedzy o sobie, mającej statyczny i/lub kreatywny charakter. Elementem wspomagającym nauczyciela, jak już wyżej zauważono, jest wyobraźnia, jakiej nauczyciel może być pozbawiony. Gwarantuje uświadomienie tego, kim jestem jako człowiek i pracownik w oświatowej wspólnocie. Chodzi tu o to, że

bycie w świecie nie polega na określeniu związku psychicznej czy fizycznej obecności osoby, ale stwierdzenia istnienia świadomości, że tuż obok mnie są inne podobne do mnie podmioty (...). Nie jestem jakimś ,ja”", które jest niezależne nawiązujące dopiero więzi z innymi, lecz od początku jestem otwarty na spotkanie $\mathrm{z}$ innymi ${ }^{38}$.

Przywołany cytat B. Zamorskiej wpisuje się w koncepcję I. Mentera, wskazując, że nauczyciel nie jest jedyną ważną osobą w systemie kształcenia, ale jedną z osób w wielotysięcznej masie. Stara się tam rzetelnie wywiązywać ze swoich powinności, umacniając swoją indywidualną i zawodową tożsamość39. Szczególnie przydatna jest postawa nastawiona na otwartość, elastyczność i ciekawość, w której może pojawić się iskierka zachęcająca do odkrywania w pracy czegoś nowego i oryginalnego. Ten sposób zawodowego bycia nauczyciela ujawnia się w konkretnych przestrzeniach i na ich pograniczu. Dla podkreślenia wyrazistości tożsamości nauczyciela i jego aktywności na pograniczu różnych przestrzeni D.J. Clandinin i F.M. Connelly używają wyrażenia professional knowledge landscape ${ }^{40}$. Dotyczy ono szerokiego wpływu rzeczy, osób i miejsc, pośród których toczy się życie nauczyciela widziane nie tylko jako efekt konstruowania siebie, ale i rezultat społecznego kompromisu wypracowującego zawodowy konsensus.

W każdym z tych nauczycielskich działań występują procesy metanauczania wynikające z uzyskanych kompetencji i przyswojenia zasad funkcjonowania w placówce. Kwalifikacje nauczyciela i reguły instytucjonalne intensyfikują jego indywidualne umiejętności oraz predyspozycje do inspirowania

${ }^{36}$ E. Wenger, Communities of practice, s. 45-48; P. Kleiman, Towards transformations of creativity in higher education, Innovation in Education and Teaching International, 2008, 45, s. 3 i 213.

37 Różne sposoby uczenia się człowieka, to m.in. aktywne metody, memotechniki, peer learning $\mathrm{i}$ inne.

38 B. Zamorska, Codzienność granic, s. 116.

${ }^{39}$ Ch. Day,. Nauczyciel z pasją. Jak zachować entuzjazm i zaangażowanie w pracy, Gdańsk 2008.

${ }^{40}$ D.J. Clandinin, F.M. Connelly, Narrative inquiry: Experience and story in qualitative research, San Francisco 2000, s. 5. 
wspólnotowej pracy, uczenia się i aktywności dla dobra swojego oraz innych. Angażują nauczyciela w tworzenie się różnych wymiarów jego tożsamości poprzez:

- krytyczną refleksję na temat „bycia nauczycielem”,

- analizę postaw wobec uniwersyteckiego uczenia się oraz uczenia w miejscu pracy,

- uznanie występowania różnych kontekstów aktywności nauczyciela,

- zastanowienie się nad skutecznym zorganizowaniem zawodowych doświadczeń wzbogacających praktykę,

- rozpatrzenie krytyki skierowanej pod adresem jakości uczenia się nauczyciela,

- uwzględnienie krytycznego podejścia do zdobywanych informacji o sobie i wykonywanym zawodzie,

- pielęgnowanie poczucia wspólnotowych wartości grupowych,

- wyznaczanie realistycznych celów osobistych i zawodowych przez nauczyciela,

- umiejętne wyszukiwanie rozwiązań teoretycznych i praktycznych oraz ich właściwe ocenianie ${ }^{41}$.

W wyróżnione przez A. Graham i R. Phepls zawodowe cele nauczyciela, a uwzględnione przez I. Mentera są wpisane procesy metapoznawcze. Wzmacniają one zdolności nauczyciela do przyswajania wiedzy i doświadczenia w czasie edukacji własnej, jak i w miejscu pracy. Zasygnalizowana strategia uczenia przenosi się na czas bycia osobą dorosłą uprawiającą wybrany zawód. Wobec tego, skuteczność nauczycielskiej profesji wiąże się z zaangażowaniem lub jego brakiem, wynikającym z wcześniejszego podejścia do uczenia się i aktywności łączącej się z poznaniem, jak „być nauczycielem”. Zdaniem E. Wattsa, takiej aktywnej postawie nauczyciela sprzyja indywidualna i grupowa stymulacja oraz umiejętność równoważenia zróżnicowanych obszarów indywidualnego i instytucjonalnego funkcjonowania poprzez:

- rozwijanie tożsamości „bycia nauczycielem,

- zwiększenie umiejętności uczenia się powiększającego repertuar posiadanej wiedzy,

- świadome identyfikowanie się z systemem wiedzy środowiska szkolnego,

- dostrzeganie przez nauczyciela edukacji z różnych perspektyw,

- rozwijanie własnej indywidualnej potrzeby uczenia się,

- zachęcanie do swobodnego, osobistego i zawodowego rozwoju,

- wspieranie odpowiedzialności za wykonywanie nauczycielskich obowiązków ${ }^{42}$.

41 A. Graham, R. Phelps, Bening a teacher, s. 5.

42 Tamże, s. 8. 


\section{Podsumowanie}

Reasumując całość przedstawionego wywodu, nasuwa się stwierdzenie, że tożsamość nauczyciela i jej różne wymiary nie kształtują się tylko w osobowej przestrzeni własnego „,ja”, ale dostrzegania siebie jako cząstki nauczycielskiej wspólnoty widzącej swoją osobę w grupie, jako osoby zdolnej do podjęcia każdej działalności pojawiającej się w wielorakich przestrzeniach i na ich pograniczu. Generuje to nadążanie za cywilizacyjnym postępem, jak i identyfikowaniem jednostkowej twarzy, bez której siły i edukacyjnego zaangażowania, krytycznej refleksji oraz wsparcia nie byłoby otwartości na własne wnętrze, które uchyla drzwi na zewnętrzny świat. Przekłada to się na aktywny i dynamiczny proces uczenia, budowania i równoważenia obszarów swojej nauczycielskiej tożsamości, by interesująco edukować młode pokolenie. Sprecyzowaną tezę dopełnia myśl A. Einsteina, który napisał, że „wielkim kunsztem wykazuje się nauczyciel, który potrafi sprawić, że twórcze wyrażanie siebie i nabywanie wiedzy staje się źródłem radości" ${ }^{43}$, przekładającym się na wartościowo realizowany proces dydaktyczno-wychowawczy.

\section{BIBLIOGRAFIA}

Ball S.J., Self and identity in the context of deviance: the case of criminal abortion. Theoretical perspectives of deviance, New York 1972.

Bauman Z., Niecodzienność nasza codzienność, [w:] Barwy codzienności. Analiza socjologiczna, red. M. Bogunia-Borowska, Warszawa 2009.

Beijaard D., Meijer P.C., Verloop N., Reconsidering research on teachers' professional identity, Teaching and Teacher Education, 2004, 20.

Biggs J., The role of metalearning in study processes, British Journal of Educational Psychology, 1985, 55.

British Educational Research Journal, 2003, 29(2).

Castañeda J.A.F., Teacher identity construction: exploring the nature of becoming a primary school language teacher, November 2011.

Clandinin D.J., Connelly F.M., Narrative inquiry: Experience and story in qualitative research, San Francisco 2000.

Cohen J.N., Getting recognized: Teachers negotiating professional identities as learners through talk, Teaching and Teacher Education, 2010, 26.

Cooper R.K., Sawal A., Inteligencja emocjonalna w organizacji i zarzadzaniu, Warszawa 2000.

Cupryjak M., Tożsamość w kontekście transformacji. Raport z badań, http://dx.doi. org/10.12775/PBEE.2013.

Day Ch., Nauczyciel z pasją. Jak zachować entuzjazm i zaangażowanie w pracy, Gdańsk 2008.

Dewy J., Jak myślimy, przekł. J. Mysłakowski, Lwów - Warszawa 1934.

Dróżka W., Generacja wielkiej zmiany. Studium autobiografii średniego pokolenia nauczycieli polskich, Kielce 2008.

${ }^{43}$ www.zlotemysli.AlbetEinstein.pl [dostęp: 24.02.2014]. 
Dyer J., Language and identity, The Routledge Companion to Sociolinguistics, London 2007. Goffman E., Stigma: Notes on the management of spoiled identity, London - New Jersey 1963.

Gołębniak B., Ku pedeutologii refleksyjnej - od agresywnej pewności do tagodnej perswazji, Teraźniejszość - Człowiek - Edukacja, numer specjalny, Wrocław 2001.

Graham A., Phelps R., Bening a teacher: developing teacher identity and enhancing practice through metacognitive and reflective learning processes, Australian Journal of Teacher Education, 2003, 27, 2.

Groningen R., Teacher's sense of their professional identity, Esther T. Canrinus, 2011.

Jackson N., Developing the concept on metalearning, Innovations in Education and Teaching International, 2004, 41, 4.

Jarynowicz M., Spostrzegać samego siebie, Studia Psychologiczne, 1989, 27, 2.

Johnson K.E., Every experience is moving force": identity and growth through mentoring, Teaching and Teacher Education, 2003, 19.

Karolczak-Biernacka B., Poczucie tożsamości i czynniki ją zakłócające, Zdrowie Psychiczne, 1992, 1-2.

Kleiman P., Towards transformations of creativity in higher education, Innovation in Education and Teaching International, 2008, 45.

Klus-Stańska D., Mentalne zniewolenie nauczycieli wczesnej edukacji - epizod czy prawidtowość, Problemy Wczesnej Edukacji, 2005, 1.

Kwiatkowska H., Edukacja nauczycieli. Konteksty. Kategorie. Praktyki, Warszawa 1997.

Kwiatkowska H., Tożsamość nauczycieli. Między anomia a autonomia, Gdańsk 2005.

Mead M., Mind, Self, and Society, Chicago 1934.

Melchior M., Spoteczna tożsamość jednostki, Warszawa 1990.

Michalski K., Logika i czas, Warszawa 1988.

Olczak-Krzyżanowska B., Poczucie tożsamości zawodu nauczyciela, Nauczyciel i Szkoła, 1999, $1(6)$.

Stownik wspótczesnego języka polskiego, red. A. Sikorska-Michalak, O. Wojniłko, Warszawa 1998.

Środa M., Indywidualizm i jego krytycy, Warszawa 2003.

Van Veen K., 'Analysing teachers' working conditions from the perspective of teachers as professionals: The case of Dutch high school teachers, [w:] Critiquing praxis: Conceptual and empirical trends in the teaching profession, red. J. Ax, P. Ponte, Rotterdam 2008.

Wenger E., Communities of practice: learning, meaning and identity, Cambridge 1999.

Witkowski L., Tożsamość i zmiana. Wstęp do epistemologicznej analizy kontekstów edukacyjnych, Torun 1988.

Wojnar I., Bergson, Warszawa1985.

Zamorska B., Codzienność granic jako miejsce kształtowania się tożsamości nauczycieli, Forum Oświatowe, 2012, 1(46). 